Original Research Paper

\title{
Investigation of some Zoonotic Viruses at South Western of Saudi Arabia
}

\author{
Ali S. Alqahtani \\ Department of Medical Laboratory Sciences, College of Applied Medical Sciences, Najran University, KSA
}

Article history

Received: 03-04-2020

Revised: 17-04-2020

Accepted: 23-04-2020

Email: almezherali@gmail.com

\begin{abstract}
Saudi Arabia is one of the most important countries as a source of horses in the world. This study was applied on the horses in Najran area, southwest Saudi Arabia. Horses were screened for three arthropods borne viral diseases; African horse sickness (AHS), West Nile Virus (WNV) and Equine Infectious Anemia (EIA) as well as one bacterial disease, brucellosis. Ninety two blood samples were collected from seven horse stables in the period from March to November 2017. ELISA was used for detection of AHS, WNV and EIA, while Rose Bengal Plate Test (RBPT) was used for brucellosis. The results showed that 14 samples were positive for anti-WNV IgG with percent of $15.2 \%$, while all samples were negative for anti-WNV IgM. Furthermore, 9.78\%, of samples were positive for brucellosis. The infection was shown only in three stables, where horses are in close contact with ruminants. Horses were free of AHS and EIA. For the first time, brucellosis and WNV were detected in horse in Najran area of KSA. However, more investigations are required to further examine the brucellosis samples.
\end{abstract}

Keywords: Brucellosis, Horses, WNV, AHS, EIA

\section{Introduction}

Arboviruses are wide group of viruses that have a worldwide distribution and belonging to many different taxonomic families. AHS of Reoviridae, WNV of Flaviviridae and EIA of Retroviridae are known three arbovirus viruses that cause infection in horses (Gubler, 2002). Culicoides imicola, the main vectors of these is present in SA and neighboring countries as Yemen (Boorman, 1989; Al-Ahmed et al., 2010). African horse sickness was restricted to sub-Saharan Africa (Awad et al., 1981) until 1959 when the virus spread onto some countries of Asia continent including Saudi Arabia (Rafyi, 1961; Mirchamsy and Hazrati, 1973; Gohre et al., 1964). Thirty years later in 1989 and 1990, AHS was identified in south region of Saudi Arabia. After this outbreak, routine surveillance of the AHS was performed by the authority. Many studies in different localities indicated that the kingdom is free of the virus (Al-Afaleq et al., 1989; Hemida et al., 2017; APHIS, 2015). A recent study of suspected AHS in the southwestern of the kingdom showed that some horses developed clinical symptoms which might be related to the AHS infection. The study indicated the importance of a new surveillance study of AHS in the southwestern area of Saudi Arabia (Al-Ghamdi, 2017). WNV was first isolated in 1937 in the West Nile region of Uganda (CDC, 2016). From the 1950s to the 1980s, the virus spread to different countries of Europe, Africa, Australia, America and Asia (Smithburn et al., 1940; Work et al., 1953; Schmidt and Elmansoury, 1963; Tber, 1996; Nash et al., 2001; Malkinson et al., 2002). Since the beginning of the 21 st century, WNV has emerged in the form of epidemics and outbreaks in human and horses in North America and Europe (DOHMH, 2012; Trock et al., 2001). The presence of WNV antibodies in almost one third of tested horses in Al-Ahsa area, east of Saudi Arabia (Al-Ghamdi, 2014) was proved. Other study proved the presence of arthropods vectors of WNV in Saudi Arabia (Al-Ali et al., 2008). EIA was found in donkies in the southwest survey of Saudi Arabia (Sellon, 1993). The clinical signs of the disease include recurrent fever, weight loss, edema and anemia (Sellon, 1993) Brucellosis is a zoonotic disease which mainly infects cattle, sheep and goats (WHO, 1986). It causes severe economic losses in livestock and infects more 
than 500,000 human every year (WHO, 1986). The brucellosis threat is higher in Saudi Arabia; as it import high numbers of livestock especially during the Hajj season. In addition, there is a high amount of uncontrolled animal movement across the borders of neighboring countries (Kiel and Yousuf Khan, 1989). The results of previous studies conducted on brucellosis in Saudi Arabia showed that the ratio was $1.7-15 \%$ in human and $14.2-26.1 \%$ in sheep and goats (Al-Zeftawi et al., 1986; Radwan et al., 1983; Asaad and Alqahtani, 2012; Elsheikh et al., 2011; Scott et al., 2016; Memish, 2001; Al-Sekait, 1999). Brucella abortus infection in equine has been detected in different parts of the world; the infection ranged from 0.5 to $40 \%$. In most conducted studies, ruminant seems to be the principle source of infection (Denny, 1073; Abo-Shehada, 2009; Acosta-González et al., 2006). This study was conducted in the Najran area in southwestern Saudi Arabia to investigate the prevalence of these viral and bacterial diseases.

\section{Material and Methods}

\section{Sample Collection}

A total of 92 blood samples were obtained from 7 horse stables from March 2017 to November 2017. Five $\mathrm{ml}$ of blood was collected from each horse in sterile tubes and was transported to the laboratory. After blood clotting, it was centrifuged at 5,000 rpm for $5 \mathrm{~min}$ and sera were separated and stored in labeled cryovials at $-20^{\circ} \mathrm{C}$ till used. Ethical rules and animal welfare were taken into account during sampling.

\section{Serological Tests}

\section{A. ELISA}

AHS kit was obtained from INGENASA, Madrid, Spain and the test was done as previously described (Hamblin et al., 1990). Detection of anti-WNV IgG: Sera were investigated for West Nile virus specific antibodies using ID screen WNV competition multi species ELISA (ID Vet, Grables, France). The test depends on recognition of WNV anti-pre-E antibodies in horse sera.
The test was applied according to the manufacturer's instructions. For detection of anti-WNV IgM infection in horses, a commercially available IgM capture ELISA was used (IDEXX IgM WNV Ab Test, USA) according to the manufacturer's instructions. EIA kit was obtained from INGENASA, Madrid, Spain and the test was applied as described by the supplier.

\section{B. Rose Bengal Plate Test}

RBPT antigen was purchased from (VLA, U.K.) and the technique was used as previously described (Alton et al., 1988). Briefly, all the reagents were brought to room temp before use. One drop of antigen was mixed with one drop of serum on white glass slide. The antigen and the serum were mixed thoroughly and the results were recorded after 3-4 min of gentle shaking.

\section{Results}

Serologic testing for anti-WNV IgG antibodies detected antibodies titer in 14 samples of 92 tested samples, with percent of $15.2 \%$ (Table 1). The positive samples were shown in all of the tested seven stables. The case history of tested positive horses indicated no clinical signs or previous vaccination. On the other side, all the 92 investigated samples by antiWNV IgM antibodies were negative. These results confirm the absence of recent infections. Follow up with horse owners revealed no clinical symptoms, or any mortality among WNV positively identified horses. All 92 tested samples were negative for both AHS and EIA viruses. Moreover, 9 samples were positive for B. abortus with percent of $9.78 \%$. All the positive samples were shown only in three stables of the seven tested ones, while other four stables were negative. Interestingly, these positive results were shown only in the presence of ruminant as camel and sheep close to horses (Table 1). The positive samples were shown in both males and females, which indicate that both sexes could be infected.

Table 1: The serological results of tested viral and bacterial diseases

\begin{tabular}{lllllll}
\hline Stables & $\begin{array}{l}\text { Number of } \\
\text { samples }\end{array}$ & $\begin{array}{l}\text { Number of WNV-IgG } \\
\text { positive (percentage) }\end{array}$ & $\begin{array}{l}\text { Number of WNV-IgM } \\
\text { positive (percentage) }\end{array}$ & $\begin{array}{l}\text { Number of brucellosis } \\
\text { positive (percentage) }\end{array}$ & $\begin{array}{l}\text { Number of AHS } \\
\text { positive (percentage) }\end{array}$ & $\begin{array}{l}\text { Number of EIA } \\
\text { positive (percentage) }\end{array}$ \\
\hline 1 & 10 & $2(20 \%)$ & $0(0 \%)$ & $0(0 \%)$ & $0(0 \%)$ & $0(0 \%)$ \\
2 & 26 & $4(15.3 \%)$ & $0(0 \%)$ & $5(19.2 \%)$ & $0(0 \%)$ & $0(0 \%)$ \\
3 & 10 & $1(10 \%)$ & $0(0 \%)$ & $0(0 \%)$ & $0(0 \%)$ & $0(0 \%)$ \\
4 & 12 & $3(25 \%)$ & $0(0 \%)$ & $0(0 \%)$ & $0(0 \%)$ & $0(0 \%)$ \\
5 & 11 & $2(18.1 \%)$ & $0(0 \%)$ & $2(18.1 \%)$ & $0(0 \%)$ & $0(0 \%)$ \\
6 & 10 & $1(10 \%)$ & $0(0 \%)$ & $0(0 \%)$ & $0(0 \%)$ & $0(0 \%)$ \\
7 & 13 & $1(7.6 \%)$ & $0(0 \%)$ & $2(15.3 \%)$ & $0(0 \%)$ & $0(0 \%)$ \\
Total & 92 & $14(15.2 \%)$ & $0(0 \%)$ & $9(9.78 \%)$ & $0(0 \%)$ & $0(0 \%)$ \\
\hline
\end{tabular}




\section{Discussion}

Horses were associated with humans from ancient times, especially in Arabian Peninsula. Horses should be observed and taken care of because any infection may affect humans. Najran area in the Southwest border of Saudi Arabia has shown many emerging viral disease as MERS and Dengue in the last few years (Madani et al., 2014; WHO, 2017). Because of the presence of endemicity of brucellosis in human and animals and the presence of mosquito that transmits AHS, WNV and EIA and the proximity of Saudi Arabia from an infected country such as Egypt, Iran and Yemen, this study was done to investigate these diseases. Our results indicated the prevalence of $\mathrm{IgG}$ antibodies against the virus in $15.2 \%$ of tested samples while IgM antibodies was negative. Even though IgG antibodies results were lower than that performed in the Eastern part of Saudi Arabia, it confirmed the prevalence of WNV antibodies. The horses that showed WNV titer had no evidence of disease and no previous vaccination. It seems that horses attracted a mild infection in the past, without showing any signs. It is well known that most of human and horses infection went mild without symptoms or severe illness (Hayes, 1989). The virus have been identified in neighboring regions in Asia and Africa, which might be responsible for spread of the infection to SA. Our results showed that all tested sera were IgM negative which indicate that the infection of the WNV is not an acute infection.

The last outbreak of AHS was in the south area of Saudi Arabia which consider as the closest region to the AHS endemic areas in sub-Saharan Africa and Yemen (Al-Ghamdi, 2017). The World Organization for Animal Health suggests systematic monitoring of AHS at regular intervals to avoid the spread of the disease. No African horse sickness antibodies were detected in this study. Previously, Animal and Plant Health Inspection Service considered the importation of equines from Saudi Arabia to the United State presents a low risk of introducing AHS (APHIS, 2015). This result supports previous works that Saudi Arabia is free of AHS and the last infection was in 1989 (Al-Afaleq et al., 1998; Hemida et al., 2017; APHIS, 2015). Just as in the case of AHS, Presence of EIA has been excluded in Najran. It seems that the preventive strategies applied in Saudi Arabia as vectors control and good quarantine measures prevent these two diseases in the country (Howell, 1963).

Despite the endemicity of brucellosis in human and animals, equine brucellosis was not previously investigated in Saudi Arabia. The widely used RBPT is used in our study for screening of brucellosis. Although the test is simple, sensitive, cheap and convenient; cross reaction with other pathogens could results in false positive results (Erganis et al., 2005). This study showed the prevalence of brucellosis in $9.78 \%$ of all tested samples. All tested positive horses were apparently normal and did not show any signs of infection. Although the source of infection was not confirmed; ruminant probably is the source of infection. As shown in our results, the positive samples are found only in stables where horses are kept together with small or large ruminants. It is probable that the horses get infected during daily exercise by ingestion of contaminated food or water from these ruminants. Our results are in agreement with other works (Ocholi et al., 2004; Denny, 1973; Ehizibolo et al., 20211) who reported evidence of horses infection with B. abortus on the same open area with ruminants and that positive reacted horses usually show no symptoms. In fact, positive antibodies reaction does not mean brucellosis infection. The limitation of this work is absence of confirmation of the positive samples with ELISA for equine brucellosis due to lack of supplies, which need to be done in next studies.

\section{Conclusion}

Our results indicated for the first time the prevalence of WNV and brucellosis antibodies in horses in Najran. Further investigations and follow up of these disease should not be neglected. The rearing of horses in close to ruminants should be prevented to avoid cross infection. Najran area is free from AHS and EIA.

\section{Funding}

This research did not receive any specific grant from any funding agencies.

\section{Ethical Approval}

The study was approved by the Institutional Ethics Committee at Najran University.

\section{References}

Abo-Shehada, M.N., 2009. Seroprevalence of Brucella species in equids in Jordan. Vet. Rec., 165: 267-268. DOI: $10.1136 / v r .165 .9 .267$

Acosta-González, R.I., I. González-Reyes and G.H. Flores-Gutiérrez, 2006. Prevalence of Brucella abortus antibodies in equines of a tropical region of Mexico. Can. J. Vet. Res., 70: 302-304.

Al-Afaleq, A.I., E.M. Abu Elzein and M.M. Hassanein, 1998. Observations on African horse sickness in Saudi Arabia. Rev. Sci. Tech., 17: 777-780.

DOI: $10.20506 /$ rst.17.3.1132

Al-Ahmed, A.M., M.A. AlKhereiji and S.M. Kheir, 2010. Distribution of Culicoides Latreille (Diptera: Ceratopogonidae) in Saudi Arabia. J. Entomol., 7: 227-234. DOI: 10.3923/je.2010.227.234 
Al-Ali, K.H., A.A. El-Badry, A.H.A. Eassa, A.M. AlJuhani and S.F. Al-Zubiany et al., 2008. A study on Culex mosquitoes and Culex transmitted diseases in Al-Madinah, Al-Munawarah, Saudi Arabia. Parasitol. United J., 1: 101-108.

Al-Ghamdi, G., 2017. African horse sickness: A possible cause of horse fatalities in al baha southwestern of the kingdom of Saudi Arabia. Int. J. Curr. Adv. Res., 6: 4713-4714.

Al-Ghamdi, G.M., 2014. Incidence of West Nile virus in Al-Ahsa, Saudi Arabia. Int. J. Virol., 10: 163-167. DOI: 10.3923/ijv.2014.163.167

Al-Sekait, M.A., 1999. Seroepidemiology survey of brucellosis antibodies in Saudi Arabia. Ann. Saudi Med., 19: 219-222. DOI: $10.5144 / 0256-4947.1999 .219$

Alton, G.G., L.M. Jones, R.D. Angus and J.M. Verger, 1988. Techniques for the brucellosis laboratory. INRA, Paris.

Al-Zeftawi, M. Al-Issa, S. Bakair and A. Al-Mukayl, 1986. Epidemiology of brucellosis among abattoir workers in Saudi Arabia. Ann. Saudi Med., 6: 29-31.

APHIS, 2015. USDA. Notice of determination of the African Horse Sickness Status of Saudi Arabia. Animal and Plant Health Inspection Service.

Asaad, A.M. and J.M. Alqahtani, 2012. Serological and molecular diagnosis of human brucellosis in Najran, Southwestern Saudi Arabia. J. Infect. Public Health, 5: 189-94. DOI: 10.1016/j.jiph.2012.02.001

Awad, F.I., M.M. Amin, S.A. Salama and S. Khide, 1981. The role played by Hyalomma dromedarii in the transmission of African horse sickness in Egypt. Bull. Anim. Health Prod. Afr., 29: 337-340.

Boorman, J., 1989. Culicoides Diptera: Ceratopogonidae of Arabian Peninsula with notes on their medical and veterinary importance. Fauna Saudi Arabia, 10: 160-224.

CDC, 2016. West Nile Virus. Statistics and maps. Final cumulative maps and data for 1999-2016. Atlanta.

Denny, H.R., 1073. A review of brucellosis in the horse. Equine Vet. J., 5: 121-125.

DOI: 10.1111/j.2042-3306.1973.tb03208.x

Denny, H.R., 1973. A review of brucellosis in the horse. Equine Vet. J., 5: 121-125. DOI: $10.1111 / j .2042-3306.1973 . t b 03208 . x$

DOHMH, 2012. West Nile virus. Department of Health and Mental Hygiene.

Ehizibolo, D.O., A.M. Gusi, P.O. Ehizibolo, E.U. Mbuk and R.A. Ocholi, 2011. Serologic prevalence of brucellosis in horse stables in two northern States of Nigeria. J. Equine Sci., 22: 17-19.

DOI: $10.1294 /$ jes. 22.17

Elsheikh, A.A., E.E. Masoud, M.F. Mostafa and M.M. Elkhawanky, 2011. Seroprevalence of 2 zoonotic diseases in Southwestern Saudi Arabia. Rift Valley fever and brucellosis. Saudi Med. J., 32: 740-741.
Erganis, O., H.H. Hadimli, H. Solmaz and M. Corlu, 2005. Comparison of rose Bengal plate test antigens prepared from Brucella abortus, Brucella melitensis and Brucella suis. Bull. Vet. Inst. Pulawy, 49: 165-167.

Gohre, D.S., J.B. Khot, V.L. Paranjpe and S.L. Manjrekar, 1964. Observations on the outbreak of South African horse sickness in India during 19601961. Bombay Vet. Coll. Mag., 1964-1965; 5-15.

Gubler, D.J., 2002. The global emergence/resurgence of arboviral diseases as public health problems. Arch. Med. Res., 33: 330-342.

DOI: $10.1016 / \mathrm{S} 0188-4409(02) 00378-8$

Hamblin, C., S.D. Graham, C. Andersone, J.R. Crowther, 1990. A competitive ELISA for the detection of group-specific antibodies to African horse sickness virus. Epidemiol. Infect., 104: 303-312. DOI: $10.1017 / \mathrm{S} 0950268800059483$

Hayes, C.G., 1989. West Nile Fever. In: The Arboviruses: Epidemiology and Ecology, Monath, T.P. (Ed.), CRC Press, Inc., Boca Raton, FL, pp: 59-99.

Hemida, M., M. Alhammadi, A. Daleb and A. Alnaeem, 2017. Molecular and serological surveillance of African horse sickness virus in Eastern and Central Saudi Arabia. Rev. Sci. Tech. Off. Int. Epiz., 36: 2722-2725. DOI: 10.20506/rst.36.3.2722

Howell, P.G., 1963. African horse sickness, in: Emerging diseases of animals, FAO, Rome FAO Agricultural Studies.

Kiel, F.W. and M. Yousuf Khan, 1989. Brucellosis in Saudi Arabia. Soc. Sci. Med., 29: 999-1001. DOI: 10.1016/0277-9536(89)90056-7

Madani, T.A., E.I. Azhar, T.M. Abuelzein, M. Kao and H.M. Al-Bar et al., 2014. Complete genome sequencing and genetic characterization of Alkhumra hemorrhagic fever virus isolated from Najran, Saudi Arabia. Intervirology, 57: 300-303. DOI: 10.1159/000362334

Malkinson, M., C. Banet, Y. Weisman, S. Pokamunski and R. King et al., 2002. Introduction of West Nile virus in the Middle East by migrating white storks. Emerg. Infect. Dis., 8: 392-397. DOI: 10.3201/eid0804.010217

Memish, Z., 2001. Brucellosis Control in Saudi Arabia: Prospects and challenges. J. Chemotherapy, 1: 11-17. DOI: 10.1080/1120009X.2001.11782322

Mirchamsy, H. and A. Hazrati, 1973. A review of the aetiology and pathology of African horse sickness. Arch. Inst. Razi., 25: 23-46.

Nash, D., F. Mostashari, A. Fine, J. Miller and D. O'Leary et al., 2001. The outbreak of West Nile virus infection in the New York City area in 1999. N. Engl. J. Med., 344: 1807-1814. DOI: $10.1056 /$ NEJM200106143442401 
Ocholi, R.A., W.J. Bertu, J.P. Kwaga, I. Ajogi and J.O. Bale et al., 2004. Carpal bursitis associated with Brucella abortus in a horse in Nigeria. Vet. Rec., 155: 566-567. DOI: 10.1136/vr.155.18.566

Radwan, A., J. Asmer, W. Frehichs, S. Bekair and A. AlMukayl, 1983. Incidence of brucellosis in domestic livestock in Saudi Arabia. Tropical Anim. Health Product., 15: 139-143. DOI: 10.1007/BF02239921

Rafyi, A., 1961. Horse sickness. Bull. Off. Int. Epizoot., 56: $216-250$.

Schmidt, J.R. and H.K. Elmansoury, 1963. Natural and experimental infection of Egyptian equines with West Nile virus. Ann. Trop. Med. Parasitol., 57: 415-427. DOI: 10.1080/00034983.1963.11686194

Scott, J.N., M.A. Assiri, A.Z. Memish and D.A. Aloufia, 2016. Trends of reported human cases of brucellosis, Kingdom of Saudi Arabia, 2004-2012. J. Epidemiol. Global Health, 6: 11-18. DOI: 10.1016/j.jegh.2015.09.001

Sellon, D.C., 1993. Equine infectious anaemia. Vet. Clin. North Am-EqPrac., 9: 321-335.

DOI: $10.1016 /$ S0749-0739(17)30399-1
Smithburn, K.C., T.P. Hughes, A.W. Burke and J.H. Paul, 1940. A neurotropic virus isolated from the blood of a native of Uganda. Am. J. Trop. Med., 20: 471-492. DOI: 10.4269/ajtmh.1940.s1-20.471

Tber, A., 1996. West Nile fever in horses in Morocco. Bull. Int. Epizoot., 11: 867-869.

Trock, S.C., B.J. Meade, A.L. Glaser, E.N. Ostlund and R.S. Lanciotti et al., 2001. West Nile virus outbreak among horses in New York State, 1999 and 2000. Emerg. Infect. Dis., 7: 745-747.

DOI: $10.3201 /$ eid0704.017427

WHO, 1986. 6th report of the joint FAO/WHO Expert Committee on brucellosis. WHO Technical Reports Series, WHO, Geneva.

WHO, 2017. Middle East respiratory Syndrome coronavirus (MERS-CoV) - Saudi Arabia. WHO.

Work, T.H., H.S. Hurlbut and RM. Taylor, 1953. Isolation of West Nile virus from hooded crow and rock pigeon in the Nile delta. Proc. Soc. Exp. Biol. Med., 84: 719-722.

DOI: $10.3181 / 00379727-84-20764$ 